\title{
The Incidence of Linezolid Induced Lactic Acidosis in Post GIT- Operative Patients
}

\author{
HAGER A. GABR, M.Sc.; TAREK S. SHABANA, M.D.; MOSTAFA M. HUSSEIN, M.D. and \\ NOHA M. ELSHARNOUBY, M.D.
}

The Department of Anesthesia, Intensive Care \& Pain Management, Faculty of Medicine, Ain Shams University

\begin{abstract}
Background: Linezolid (LZD) is antibiotic belonging to Oxazolidinones group. It acts by protein synthesis inhibition and has clinical utility in the treatment of infections caused by resistant aerobic Gram-positive bacteria (as methicillinresistant S. aureus (MRSA), Vancomycin Resistant Enterococci (VRE), and mycobacterial infections).

Aim of Study: To evaluate the incidence of linezolid induced lactic acidosis in post GIT-operative patients.

Patients and Methods: After ethical committee approval, 150 patients admitted to the intensive care unit (ICU) after gastrointestinal tract surgery were enrolled in this retrospective cohort study, Patients were divided into two equal groups: those who used LZD and those who used Vancomycin (VAN), to examine the incidence of lactic acidosis after administration of either LZD or VAN. Patients with other risk factors for lactic acidosis were excluded from the study. Demographic data, admission diagnosis and the result of laboratory examinations were recorded. The duration of antibiotic use and the use of other antibiotics were recorded from patient's medical chart.

Results: The incidence of lactic acidosis was statistically significance higher in patients on LZD therapy than in those on VAN therapy ( $13.3 \%$ vs. $1.3 \%$, respectively, $p=0.005)$. The mortality rate after antibiotic administration was higher (but doesn't reach statistical significance) in patients on LZD therapy compared to those on VAN therapy $(25.3 \%$ vs. $17.3 \%$, respectively, $p=0.232$ ). In binomial logistic regression, patients on LZD therapy were statistically significance more likely to have lactic acidosis than patients on VAN therapy by approximately 11 times (crude OR=11.385; 95\% CI=1.419-91.352; $p=0.022$ ), while age, gender, presence of comorbidity, duration, and mean fluid balance after drug intake were not statistically significance associated with a change in the probability of developing lactic acidosis. However, when these factors were entered together in the regression analysis, increase in mean fluid balance was statistically significance associated with reduced likelihood of developing lactic acidosis (adjusted $\mathrm{OR}=0.998,95 \%$ C.I. $=0.996-1.000, p=0.047)$.
\end{abstract}

Conclusion: LZD was not associated with significant higher incidence of lactic acidosis in comparison to Vancomycin in post GIT operative patients.

Correspondence to: Dr. Hager A. Gabr, E-Mail:gogo.jber@live.com
Key Words: Linezolid-induced lactic acidosis - Post GIToperative patients.

\section{Introduction}

LINEZOLID is a synthetic antibacterial agent of a new class of antibiotics, the Oxazolidinones, which has clinical utility in the treatment of infections caused by aerobic Gram-positive bacteria that are resistant to other antibiotics [1].

Linezolid is active against most Gram-positive bacteria that cause disease, including streptococci, Vancomycin-resistant enterococci (VRE), and methicillin-resistant Staphylococcus aureus (MRSA)). The main uses are infections of the skin and pneumonia although it may be used for a variety of other infections including drug resistant tuberculosis [1]

Linezolid, like other Oxazolidinones, is a bacterial protein synthesis inhibitor and a weak,nonselective, reversible monoamine oxidase inhibitor. Linezolid stops the growth and reproduction of bacteria by disrupting translation of messenger RNA (mRNA) into proteins in bacterial ribosomes at the first step of protein synthesis, initiation [1]

Lactate is the normal endpoint of the anaerobic breakdown of glucose in the tissues. The lactate exits the cells and is transported to the liver, where it is oxidized back to pyruvate and ultimately converted to glucose via the Cori cycle. However, all tissues can use lactate as an energy source, as it can be converted quickly back to pyruvate and enter into the Krebs cycle. In the setting of decreased tissue oxygenation or mitochondrial dysfunction, pyruvate is not readily metabolized and its intracellular levels rise, causing lactate levels to rise proportionally. With a persistent oxygen debt and overwhelming of the body's buffering abilities (whether from long-term dysfunction or 
excessive production), hyperlacticaemia and metabolic acidosis ensue, commonly referred to as lactic acidosis [2].

Linezolid induced lactic acidosis was first reported by Apodaca and Rakita [3], and it is currently a documented adverse event associated with Linezolid treatment. The underlying mechanism may be related to mitochondrial dysfunction [3]

\section{Aim of the work:}

The current study aimed to evaluate the incidence of linezolid induced lactic acidosis in post GIT-operative patients.

\section{Patients and Methods}

This retrospective cohort study was carried out on 150 patients who underwent GIT surgery and were admitted to the intensive care unit (ICU) of Ain Shams University Hospitals and Tanta Cancer Institute, during the period from January 2015 to December 2019. The study commenced after obtaining approval from the Ethical Committee of Faculty of Medicine, Ain Shams University (No. FWA 00017585) and Tanta Cancer Institute by retrospective review of the medical chart.

Patients were divided into two groups: Group one: Those who used linezolid and Group two: those who used Vancomycin. We further analyzed the study population within LZD group into lactic acidosis and non-lactic acidosis groups toevaluate the risk of incidence of linezolid associated lactic acidosis.

Exclusion criteria included Patient who refused to participate in the study, and patients who were given Linezolid or Vancomycin within 1-month, other causes that may be a contributor for lactic acidosis as Diabetic ketoacidosis, cardiogenic shock, hypovolemic shock, acute blood loss, severe heart failure, sepsis, severe trauma, chronic kidney diseases, liver disease and HIV treatments), platelet count $<100,000 / \mathrm{mm}^{3}$, and patients presented with lactic acidosis were excluded from the study.

\section{Study tools:}

Demographic data, admission diagnosis and the result of laboratory examinations were recorded. The duration of antibiotic use and the use of other antibiotics were recorded.

After enrollment in the study, patients in both groups were compared for:

1- Incidence of lactic acidosis after administering antibiotics based on daily arterial blood gases (if lactic acid and arterial PH data are available, lactic acidosis was evaluated directly; if there are no data, it was evaluated indirectly by anion gap. The anion gap was calculated by using the formula $([\mathrm{Na}+]+[\mathrm{K}+])([\mathrm{Cl}-]+[\mathrm{HCO} 3-])$. The baseline result is that obtained prior to starting LZD, and the end-point result is that obtained when LZD is stopped. The change in anion gap was defined as the difference between the initial anion gap and the end-point anion gap. A case of antibiotic-associated lactic acidosis was defined as a patient first presenting with lactic acidosis after antibiotic administration. An increased anion gap event was defined as a change in anion gap $>4 \mathrm{mmol} / \mathrm{L}$ [4]

2- Hemodynamic measurement of the patient (blood pressure, pulse rate and temperature), fluid balance, urine output and CVP were recorded from patient chart daily.

3- In the case of a patient receiving multiple rounds of drug administration during thestudy period, only the first round was counted.

4- Dosage, route of daily linezolid administration and adverse effects were recorded from patients' chart until mortality or discharge.

5- Definite lactic acidosis was defined as a serum $\mathrm{pH}$ of $<7.25$ and serum lactate $4 \mathrm{mmol} / \mathrm{L}$. Probable lactic acidosis was defined as lactic acid above $4 \mathrm{mmol} / \mathrm{L}$ or acidosis of below $\mathrm{pH} 7.25$ [5].

- 1ry outcome: (Definite lactic acidosis).

- 2ry outcome: (Probable lactic acidosis, anion gap and incidence of lactic acidosis).

\section{Statistical analysis:}

Statistical analysis was performed using Statistical Package for Social Sciences (IBM SPSS Statistics) for Windows, version 26 (IBM Corp., Armonk, N.Y., USA). For quantitative data, the Shapiro-Wilk test for normality was performed. For data that followed normal distribution, values were expressed as mean \pm standard deviation. Comparisons between two groups were carried out using independent samples $t$-test and comparisons between three groups were done using one way ANOVA test (followed by post-hoc test if significant). For data that did not follow normal distribution, median and range were calculated; Wilcoxonsigned rank test was used to compare between two paired groups.

Correlations between ordinal variable (NYHA class) and numerical variables were tested using Spearman's rank-order correlation. For qualitative 
data, the variables were summarized as frequencies (count and percentage). Pearson's Chi square test for independence, Fisher's exact test or FisherFreeman-Halton exact test was used to examine association between two categorical variables as appropriate [6].

\section{Sampling method:}

Using STATA program, setting alpha error at $5 \%$ and power at $80 \%$ result from previous study (Mori et al., 2018) showed that the incidence of lactic acidosis in LZD was $10.6 \%$ compared to $0.3 \%$ in VAN group based on this, 75 cases per group will be needed (150 total).

\section{Results}

The characteristics of both groups are in (Table 1 ). The mean patient age was $54.2 \pm 13.9$ years in the LZD group and 52.2 \pm 14.1 in vancomycin group. Male patients accounted for $50.7 \%$ and $49.3 \%$ of patients respectively. Only $17.3 \%$ of patients suffered from a co-morbid clinical condition in both groups. There was a difference that didn't reach statistically significance between the two groups as regards age $(p=0.400)$, gender $(p=0.870)$, or comorbidities $(p=1.000)$.

Table (1): Patients; characteristic.

\begin{tabular}{|c|c|c|c|c|c|c|}
\hline & \multicolumn{2}{|c|}{$\begin{array}{l}\text { Linezolid } \\
\text { (LZD) } \\
(\mathrm{n}=75)\end{array}$} & \multicolumn{2}{|c|}{$\begin{array}{c}\text { Vancomycin } \\
(\text { VAN) } \\
(\mathrm{n}=75)\end{array}$} & $\begin{array}{c}\text { Test } \\
\text { statistic }\end{array}$ & $\begin{array}{c}p- \\
\text { value }\end{array}$ \\
\hline \multicolumn{7}{|l|}{ Age (years): } \\
\hline $\begin{array}{l}\text { Mean } \pm \text { SD } \\
\text { (Range) }\end{array}$ & \multicolumn{2}{|c|}{$\begin{array}{c}54.2 \pm 13.9 \\
(24-86)\end{array}$} & \multicolumn{2}{|c|}{$\begin{array}{c}52.2 \pm 14.1 \\
(21-78)\end{array}$} & $0.844 \mathbf{a}$ & 0.400 \\
\hline \multicolumn{7}{|l|}{ Gender: } \\
\hline Female & 37 & $49.3 \%$ & 38 & $50.7 \%$ & $0.027 \mathbf{b}$ & 0.870 \\
\hline Male & 38 & $50.7 \%$ & 37 & $49.3 \%$ & & \\
\hline \multicolumn{7}{|l|}{ Comorbidity: } \\
\hline Absent & 62 & $82.7 \%$ & 62 & $82.2 \%$ & $0.000^{\mathbf{b}}$ & 1.000 \\
\hline Present & 13 & $17.3 \%$ & 13 & $17.3 \%$ & & \\
\hline $\mathrm{DM}$ & 7 & $9.3 \%$ & 7 & $9.3 \%$ & $0.000^{\mathbf{b}}$ & 1.000 \\
\hline Hypertension & 6 & $8.0 \%$ & 10 & $13.3 \%$ & $1.119^{\mathbf{b}}$ & 0.290 \\
\hline $\begin{array}{l}\text { Bronchial } \\
\text { asthma }\end{array}$ & 2 & $2.7 \%$ & 1 & $1.3 \%$ & $\mathrm{FE}$ & 1.000 \\
\hline
\end{tabular}

a : Independent samples $t$-test.

b : Pearson's Chi square test for independence.

FE : Fisher's exact test.

$\mathrm{N}$ : Number.

SD : Standard deviation.

$p$-value $>0.05$ is considered non-significant

The most frequent gastrointestinal surgery was colectomy $(37.3 \%$ and $42.7 \%$ of patients, respectively), followed by APR (Abdominoperineal resection) (10.7\% and 9.3 of patients, respectively). (Table 2).
Table (2): Type of surgery.

\begin{tabular}{|c|c|c|c|c|}
\hline \multirow[b]{2}{*}{ Appendectomy and colectomy } & \multicolumn{2}{|c|}{$\begin{array}{l}\text { Linezolid } \\
(\mathrm{n}=75)\end{array}$} & \multicolumn{2}{|c|}{$\begin{array}{l}\text { Vancomycin } \\
\quad(n=75)\end{array}$} \\
\hline & 1 & $1.3 \%$ & 0 & $0.0 \%$ \\
\hline $\begin{array}{l}\text { Appendectomy and } \\
\text { panhystrectomy }\end{array}$ & 1 & $1.3 \%$ & 2 & $2.7 \%$ \\
\hline Abdominoperinealresection & 8 & $10.7 \%$ & 7 & $9.3 \%$ \\
\hline Colectomy & 28 & $37.3 \%$ & 32 & $42.7 \%$ \\
\hline Colectomy and nephrectomy & 1 & $1.3 \%$ & 2 & $2.7 \%$ \\
\hline Colectomy and panhystrectomy & 3 & $4.0 \%$ & 2 & $2.7 \%$ \\
\hline Colectomy and repair of hernia & 1 & $1.3 \%$ & 0 & $0.0 \%$ \\
\hline Colectomy and splenectomy & 0 & $0.0 \%$ & 1 & $1.3 \%$ \\
\hline Colostomy & 4 & $5.3 \%$ & 1 & $1.3 \%$ \\
\hline Esophagectomy & 2 & $2.7 \%$ & 4 & $5.3 \%$ \\
\hline Exploration & 2 & $2.7 \%$ & 2 & $2.7 \%$ \\
\hline Gastrectomyand colectomy & 0 & $0.0 \%$ & 1 & $1.3 \%$ \\
\hline Gastrectomy & 1 & $1.3 \%$ & 4 & $5.3 \%$ \\
\hline Hepatectomy & 1 & $1.3 \%$ & 1 & $1.3 \%$ \\
\hline Hiatus hernia with surgical repair & 1 & $1.3 \%$ & 0 & $0.0 \%$ \\
\hline Omentectomyand panhystrectomy & 3 & $4.0 \%$ & 1 & $1.3 \%$ \\
\hline Oophorectomy and colectomy & 1 & $1.3 \%$ & 0 & $0.0 \%$ \\
\hline Repair of colostomy & 3 & $4.0 \%$ & 0 & $0.0 \%$ \\
\hline Sigmoidectomy & 7 & $9.3 \%$ & 7 & $9.3 \%$ \\
\hline Triple bypass & 1 & $1.3 \%$ & 2 & $2.7 \%$ \\
\hline Whipple operation & 6 & $8.0 \%$ & 6 & $8.0 \%$ \\
\hline
\end{tabular}

The mean duration of antibiotics use was statistically significant shorter in the LZD group compared to the VAN group $(6.7 \pm 1.5$ vs. $7.5 \pm 2.0$, respectively, $p=0.009)$. A statistically significance higher percentage of patients in the LZD group administered another antibiotic than in the VAN group (46.7\% vs. $30.7 \%$, respectively, $p=0.044)$; the most frequent antibiotic was Cefepime $(30.7 \%$ and $25.3 \%$, respectively), followed by Meropenem (10.7\% and $4.0 \%$, respectively) (Table 3 ).

Table (3): Antibiotic duration and co administered antimicrobial agents.

\begin{tabular}{|c|c|c|c|c|c|c|}
\hline & \multicolumn{2}{|c|}{$\begin{array}{l}\text { Linezolid } \\
\qquad(n=75)\end{array}$} & \multicolumn{2}{|c|}{$\begin{array}{l}\text { Vancomycin } \\
\quad(n=75)\end{array}$} & $\begin{array}{c}\text { Test } \\
\text { statistic }\end{array}$ & $\begin{array}{c}p- \\
\text { value }\end{array}$ \\
\hline \multicolumn{7}{|l|}{ Duration (days): } \\
\hline $\begin{array}{l}\text { Mean } \pm \mathrm{SD} \\
\text { (Range) }\end{array}$ & \multicolumn{2}{|c|}{$\begin{array}{c}6.7 \pm 1.5 \\
(5.0-14.0)\end{array}$} & \multicolumn{2}{|c|}{$\begin{array}{c}7.5 \pm 2.0 \\
(5.0-14.0)\end{array}$} & $2.644 \mathbf{a}$ & $0.009 *$ \\
\hline \multicolumn{7}{|l|}{$\begin{array}{l}\text { Another antibiotic } \\
\text { used: }\end{array}$} \\
\hline Absent & 40 & $53.3 \%$ & 52 & $69.3 \%$ & $4.048 \mathbf{b}$ & $0.044 *$ \\
\hline Present & 35 & $46.7 \%$ & & $30.7 \%$ & & \\
\hline $\begin{array}{l}\text { Piperacillintaz- } \\
\text { obactam }\end{array}$ & 1 & $1.3 \%$ & 1 & $1.3 \%$ & $\mathrm{Fe}$ & 1.000 \\
\hline Meropenem & 8 & $10.7 \%$ & 3 & $4.0 \%$ & $2.453 \mathbf{b}$ & 0.117 \\
\hline Cefepime & 23 & $30.7 \%$ & 19 & $25.3 \%$ & $0.529 \mathbf{b}$ & 0.467 \\
\hline Clindamycin & 5 & $6.7 \%$ & 0 & $0.0 \%$ & $\mathrm{Fe}$ & 0.058 \\
\hline Clarithromycin & 0 & $0.0 \%$ & 1 & $1.3 \%$ & $\mathrm{Fe}$ & 1.000 \\
\hline Levofloxacin & 2 & $2.7 \%$ & 1 & $1.3 \%$ & $\mathrm{Fe}$ & 1.000 \\
\hline \multicolumn{7}{|c|}{$\begin{array}{l}\text { a }: \text { Independent samples } t \text {-test. } \\
\text { b : Pearson's Chi square test for ir } \\
\text { FE : Fisher's exact test. } \\
\mathrm{N}: \text { Number. } \\
\text { SD : Standard deviation. } \\
\quad \text { : Significant at } p \text {-value } \leq 0.05 \text {. }\end{array}$} \\
\hline
\end{tabular}


At day 0, vital signs (including SBP, DBP, temperature and heart rate), CVP, UOP, fluid balance and basic initial biochemistry (including $\mathrm{Na}+$, $\mathrm{K}+, \mathrm{HCO} 3-$, lactate and $\mathrm{pH}$ ) in LZD and VAN groups were analyzed without a statistically significance difference between the two groups (all $p>0.05$ ). The median SBP was $120 \mathrm{mmHg}$ for both groups; the median DBP was 78.0 and $79.0 \mathrm{mmHg}$, respectively. The mean temperature was $37.2 \pm 0.3$ and $37.3 \pm 0.3$, respectively. The mean heart rate was $88.4 \pm 16.1$ and $91.7 \pm 23.8 \mathrm{~b} / \mathrm{min}$, respectively. The mean CVP was $9.5 \pm 2.0$ and $9.2 \pm 1.8$, respectively. The median UOP was 2565 and 2500 respectively. The median fluid balance was 725 and 800 respectively. Results of the initial basic biochemistry revealed a mean $\mathrm{Na}$ level of $134.0 \pm 4.7$ and $134.5 \pm 5.3$ respectively; a mean $\mathrm{K}$ level of $3.5 \pm 0.5$ and $3.6 \pm 0.6$ respectively; the mean of HCO3 23.6 \pm 4.5 and $24.1 \pm 3.3$, respectively; a mean Lactate of $1.5 \pm 0.7$ and $1.4 \pm 0.8$, respectively; and a mean $\mathrm{pH}$ of $7.40 \pm 0.06$ and $7.39 \pm 0.05$ respectively (Tables 4,5).

Table (4): Vital signs, CVP, UOP, and fluid balance at day 0.

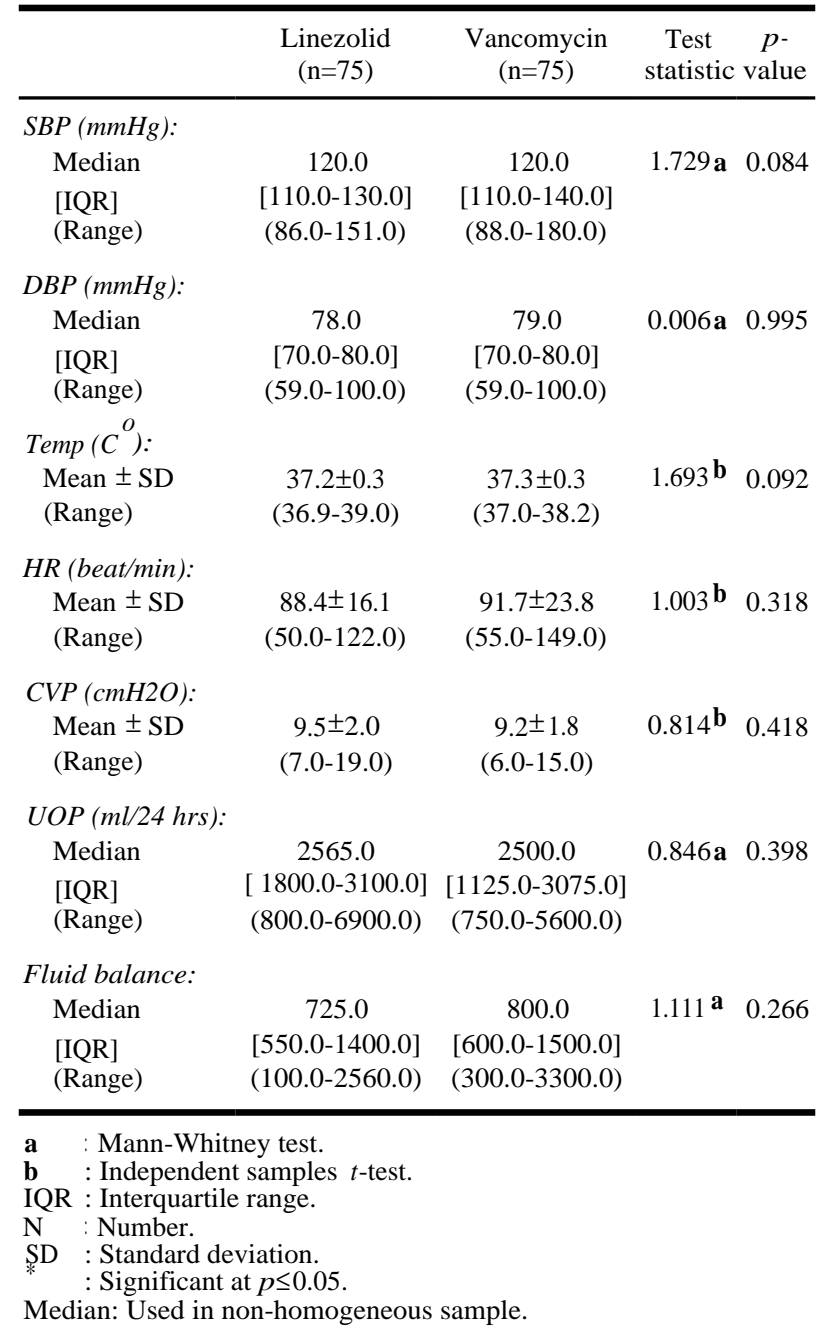

Table (5): Basic initial biochemistry at day 0 .

\begin{tabular}{|c|c|c|c|c|}
\hline & $\begin{array}{l}\text { Linezolid } \\
\quad(n=75)\end{array}$ & $\begin{array}{l}\text { Vancomycin } \\
\quad(\mathrm{n}=75)\end{array}$ & $\begin{array}{c}\text { Test } \\
\text { statistic }\end{array}$ & $\begin{array}{c}p- \\
\text { value }\end{array}$ \\
\hline \multicolumn{5}{|l|}{$N a+:$} \\
\hline $\begin{array}{l}\text { Mean } \pm \text { SD } \\
\text { (Range) }\end{array}$ & $\begin{array}{l}134.0 \pm 4.7 \\
(120.0-148.0)\end{array}$ & $\begin{array}{l}134.5 \pm 5.3 \\
(123.0-149.0)\end{array}$ & $0.687 \mathbf{a}$ & 0.493 \\
\hline \multicolumn{5}{|l|}{$K+:$} \\
\hline $\begin{array}{l}\text { Mean } \pm \text { SD } \\
\text { (Range) }\end{array}$ & $\begin{array}{l}3.5 \pm 0.5 \\
(2.4-5.3)\end{array}$ & $\begin{array}{l}3.6 \pm 0.6 \\
(2.4-5.4)\end{array}$ & $1.267 \mathbf{a}$ & 0.207 \\
\hline \multicolumn{5}{|l|}{ HCO3-: } \\
\hline $\begin{array}{l}\text { Mean } \pm \text { SD } \\
\text { (Range) }\end{array}$ & $\begin{array}{l}23.6 \pm 4.5 \\
(11.7-36.6)\end{array}$ & $\begin{array}{l}24.1 \pm 3.3 \\
(18.0-34.0)\end{array}$ & $0.715 \mathrm{a}$ & 0.476 \\
\hline \multicolumn{5}{|l|}{ Lactate: } \\
\hline $\begin{array}{l}\text { Mean } \pm \text { SD } \\
\text { (Range) }\end{array}$ & $\begin{array}{l}1.5 \pm 0.7 \\
(0.5-2.9)\end{array}$ & $\begin{array}{l}1.4 \pm 0.8 \\
(0.4-3.3)\end{array}$ & $0.773 \mathbf{a}$ & 0.441 \\
\hline \multicolumn{5}{|l|}{$p H:$} \\
\hline $\begin{array}{l}\text { Mean } \pm \text { SD } \\
\text { (Range) }\end{array}$ & $\begin{array}{l}7.40 \pm 0.06 \\
(7.26-7.53)\end{array}$ & $\begin{array}{l}7.39 \pm 0.05 \\
(7.32-7.51)\end{array}$ & $1.153 \mathbf{a}$ & 0.251 \\
\hline
\end{tabular}

a : Independent samples $t$-test.

$\mathrm{N}$ : Number.

SD : Standard deviation.

: Significant at $p \leq 0.05$.

The incidence of lactic acidosis was statistically significance higher in patients on LZD therapy than in those on VAN therapy $(13.3 \%$ vs. $1.3 \%$, respectively, $p=0.005$ ). The mortality rate after antibiotic administration was higher but did not reach statistical significance in patients on LZD therapy than that on VAN therapy $(25.3 \%$ vs. $17.3 \%$, respectively, $p=0.232$ ). 'Definite' lactic acidosis occurred in three cases $(4.0 \%)$ in LZD group, while none of the patients in the VAN group developed definite lactic acidosis; however, this difference did not reach statistical significance $(p=0.245)$. 'Probable' lactic acidosis occurred in seven cases (9.3\%) in LZD group vs. one case $(1.3 \%)$ in VAN group, which was statistically significant result $(p=0.029)$. Definite lactic acidosis was defined as a serum $\mathrm{pH}$ of $<7.25$ and serum lactate $4 \mathrm{mmol} / \mathrm{L}$. Probable lactic acidosis was defined as lactic acid above $4 \mathrm{mmol} / \mathrm{L}$ or acidosis of below pH 7.25 (Table 6).

Table (6): Incidence of lactic acidosis and death.

\begin{tabular}{lllllll}
\hline & $\begin{array}{c}\text { Linezolid } \\
(\mathrm{n}=75)\end{array}$ & $\begin{array}{c}\text { Vancomycin } \\
(\mathrm{n}=75)\end{array}$ & $\begin{array}{c}\text { Test } \\
\text { statistic }\end{array}$ & $\begin{array}{c}p \text { - } \\
\text { value }\end{array}$ \\
\hline Outcome: & & & & & & \\
$\quad$ Death & 19 & $25.3 \%$ & 13 & $17.3 \%$ & $1.430 \mathbf{a}$ & 0.232 \\
$\quad$ Discharge & 56 & $74.7 \%$ & 62 & $82.7 \%$ & & \\
& & & & & & \\
Lactic acidosis: & & & & & & \\
$\quad$ Absent & 65 & $86.7 \%$ & 74 & $98.7 \%$ & $7.946 \mathbf{a}$ & $0.005^{*}$ \\
$\quad$ Present & 10 & $13.3 \%$ & 1 & $1.3 \%$ & & \\
$\quad$ Probable & 7 & $9.3 \%$ & 1 & $1.3 \%$ & $4.754 \mathbf{a}$ & $0.029^{*}$ \\
$\quad$ Definite & 3 & $4.0 \%$ & 0 & $0.0 \%$ & $\mathrm{Fe}$ & 0.245 \\
\hline
\end{tabular}

a : Pearson's Chi square test for independence.

FE : Fisher's exact test.

$\mathrm{N}:$ Number.

: Significant at $p \leq 0.05$. 
Repeated measurements of lactate over the period of hospitalization showed that the linezolid group had an increase in median lactate level starting approximately at the eighth day, reaching the peak at the tenth day then subsided but remained above the median level in the vancomycin group (Fig. 1).

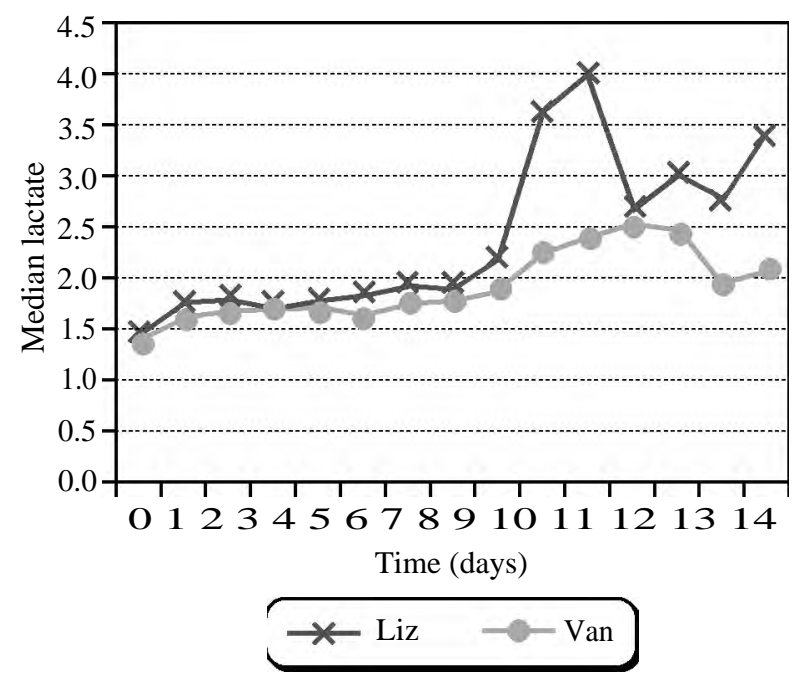

Fig. (1): Change in median lactate level over the hospitalization period in the studied groups.

Repeated measurements of $\mathrm{pH}$ over the period of hospitalization showed that the linezolid group had an increase in median $\mathrm{pH}$ starting approximately at the tenth day, reaching the peak at the 13 th day. The median $\mathrm{pH}$ in the vancomycin group remained below that of linezolid group for most of the measurements, except for a slight increase at the 9 th day (Fig. 2).

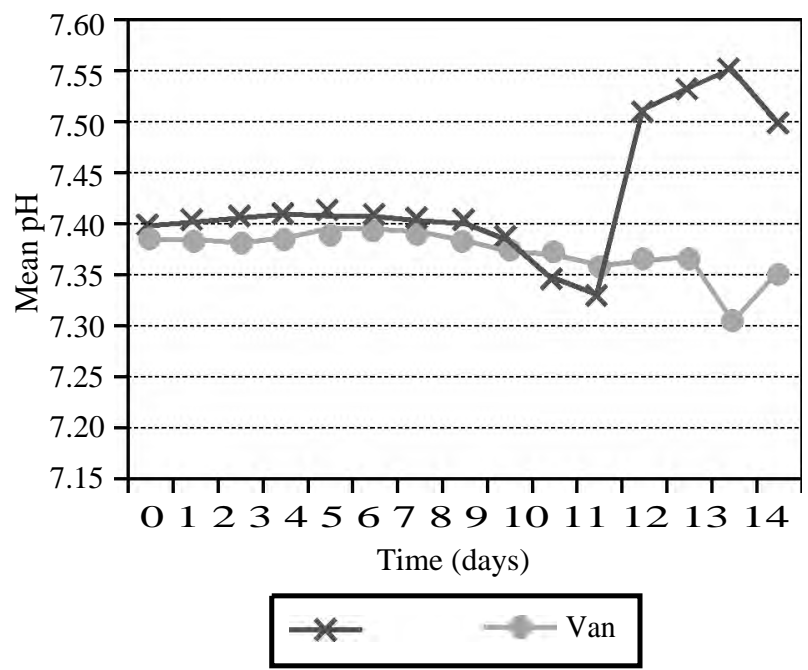

Fig. (2): Change in median $\mathrm{pH}$ over the hospitalization period in the studied groups.
To evaluate the risk of incidence of linezolid associated lactic acidosis 10 cases with lactic acidosis in LNZ therapy were compared to 65 nonlactic acidosis cases in the same group. There wasn't statistically significance difference between the two groups as regards age $(p=0.725)$, gender $(p=1.000)$, or comorbidities $(p=1.000)$, the mean duration of antibiotic use was longer in lactic acidosis group but didn't reach statistically significance. (7.4 41.5 vs $6.6 \pm 1.5$, respectively, $p=0.105$ ) (Table 7).

Table (7): Basic characteristics of cases with and without lactic acidosis in the linezolid group.

\begin{tabular}{|c|c|c|c|c|c|c|}
\hline & \multicolumn{4}{|c|}{ Linezolid group } & \multirow[b]{2}{*}{$\begin{array}{c}\text { Test } \\
\text { statistic }\end{array}$} & \multirow[b]{2}{*}{$\begin{array}{c}p- \\
\text { value }\end{array}$} \\
\hline & \multicolumn{2}{|c|}{$\begin{array}{l}\text { No lactic } \\
\text { acidosis } \\
(n=65)\end{array}$} & \multicolumn{2}{|c|}{$\begin{array}{l}\text { Lactic } \\
\text { acidosis } \\
(n=10)\end{array}$} & & \\
\hline Age (years): & \multirow{2}{*}{\multicolumn{2}{|c|}{$\begin{array}{c}54.4 \pm 14.2 \\
(24.0-86.0)\end{array}$}} & \multirow{2}{*}{\multicolumn{2}{|c|}{$\begin{array}{c}52.7 \pm 13.0 \\
(39.0-72.0)\end{array}$}} & & \\
\hline $\begin{array}{l}\text { Mean } \pm \text { SD } \\
\text { (Range) }\end{array}$ & & & & & $0.354 \mathbf{a}$ & 0.725 \\
\hline \multicolumn{7}{|l|}{ Gender: } \\
\hline Female & 32 & $49.2 \%$ & 5 & $50.0 \%$ & $\mathrm{Fe}$ & 1.000 \\
\hline Male & 33 & $50.8 \%$ & 5 & $50.0 \%$ & & \\
\hline \multicolumn{7}{|l|}{ Comorbidity: } \\
\hline Absent & 53 & $81.5 \%$ & 9 & $90.0 \%$ & $\mathrm{Fe}$ & 1.000 \\
\hline Present & 12 & $18.5 \%$ & 1 & $10.0 \%$ & & \\
\hline $\mathrm{DM}$ & 6 & $9.2 \%$ & 1 & $10.0 \%$ & $\mathrm{Fe}$ & 1.000 \\
\hline Hypertension & 6 & $9.2 \%$ & 0 & $0.0 \%$ & $\mathrm{Fe}$ & 1.000 \\
\hline Bronchial asthma & 2 & $3.1 \%$ & 0 & $0.0 \%$ & $\mathrm{Fe}$ & 1.000 \\
\hline \multicolumn{7}{|l|}{ Duration (days): } \\
\hline $\begin{array}{l}\text { Mean } \pm \mathrm{SD} \\
\text { (Range) }\end{array}$ & \multicolumn{2}{|c|}{$\begin{array}{c}6.6 \pm 1.5 \\
(5.0-14.0)\end{array}$} & \multicolumn{2}{|c|}{$\begin{array}{c}7.4 \pm 1.5 \\
(6.0-10.0)\end{array}$} & $1.640 \mathbf{a}$ & 0.105 \\
\hline \multicolumn{7}{|l|}{ Other $A B$ : } \\
\hline Absent & 36 & $55.4 \%$ & 4 & $40.0 \%$ & $\mathrm{Fe}$ & 0.500 \\
\hline Present & 29 & $44.6 \%$ & 6 & $60.0 \%$ & & \\
\hline $\begin{array}{l}\text { Piperacillintaz- } \\
\text { obactam }\end{array}$ & 0 & $0.0 \%$ & 1 & $10.0 \%$ & $\mathrm{Fe}$ & 0.133 \\
\hline Meropenem & 7 & $10.8 \%$ & 1 & $10.0 \%$ & $\mathrm{Fe}$ & 1.000 \\
\hline Cefepime & 19 & $29.2 \%$ & 4 & $40.0 \%$ & $\mathrm{Fe}$ & 0.484 \\
\hline Clindamycin & 4 & $6.2 \%$ & 1 & $10.0 \%$ & $\mathrm{Fe}$ & 0.521 \\
\hline Levofloxacin & 2 & $3.1 \%$ & 0 & $0.0 \%$ & $\mathrm{Fe}$ & 1.000 \\
\hline \multicolumn{7}{|l|}{ Outcome: } \\
\hline Death & 15 & $23.1 \%$ & 4 & $40.0 \%$ & $\mathrm{Fe}$ & 0.262 \\
\hline Discharge & 50 & $76.9 \%$ & 6 & $60.0 \%$ & & \\
\hline
\end{tabular}

a : Independent samples $t$-test.

FE : Fisher's exact test.

$\mathrm{N}$ : Number.

SD : Standard deviation.

There was difference but didn't reach statistical significance between the two groups as regards the vital sings (heart rate, SBP, DBP and temperature), urine output and fluid balance between the both groups; however, there was statistical significant difference as regrade CVP, the mean CVP was (11.8 \pm 2.1 vs $9.2 \pm 1.8$, respectively, $p=<0.001$ ), the blood chemistry including $\mathrm{Na}, \mathrm{K}$ and $\mathrm{HCO} 3$ were analyzed, without statistically significant difference between the two groups ( $p=0.860$, $p=0.776$ and $p=0.695$, respectively), The mean 
lactate was $(2.8 \pm 0.5)$ in lactic acidosis group, which was statistically significant higher than that in the non-lactic acidosis group $(1.6 \pm 0.5),(p=<0.001)$ and the mean $\mathrm{pH}(7.35 \pm 0.04 \mathrm{VS} 7.41 \pm 0.05$, respectively, $p=0.001$ ) with statistically significant difference between the two groups, (Table 8).

Table (8): Chemistry of cases with and without lactic acidosis in the linezolid group.

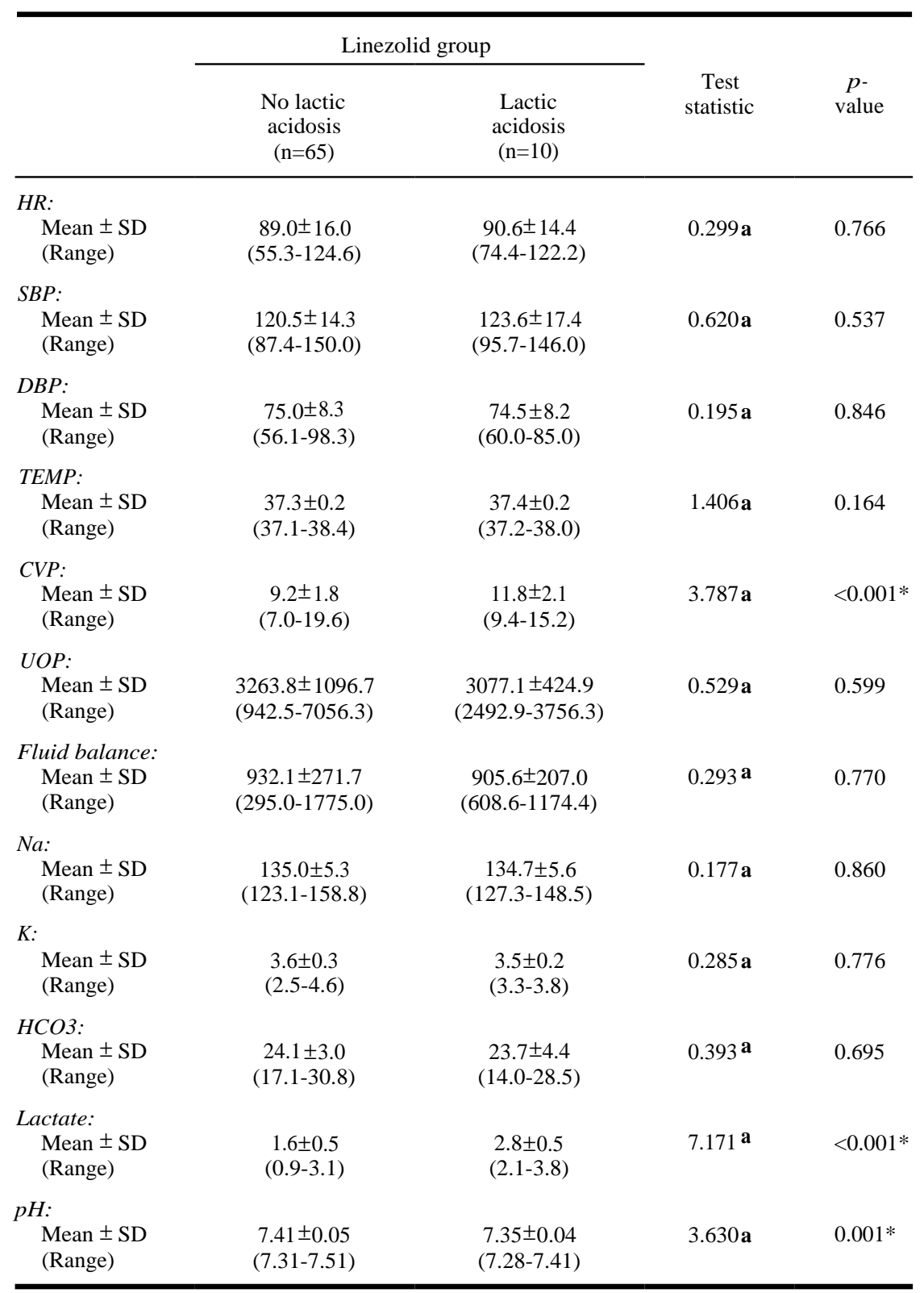

- The data represent the average of the duration of antibiotic administration.

a: Independent samples $t$-test. N: Number. SD: Standard deviation. *: Significant at $p \leq 0.05$.

Logistic regression analysis was carried out to identify variables that may have contributed to the development of lactic acidosis. When each factor was assessed individually, patients on LZD therapy were statistically significance more likely to have lactic acidosis than patients on VAN therapy by approximately 11 times (crude OR=11.385; $95 \%$ C.I=1.419-91.352; $p=0.022$ ), while age, gender, presence of comorbidity, duration, and mean fluid balance after drug intake were not statistically significance associated with a change in the probability of developing lactic acidosis. However, when these factors were entered together in the regression analysis, increase in mean fluid balance was statistically significance associated with reduced likelihood of developing lactic acidosis (adjusted $\mathrm{OR}=0.998,95 \%$ C.I. $=0.996-1.000$, $p=0.047$ ) (Table 9). 
Table (9): Binomial logistic regression analysis to identify contributing factors to lactic acidosis.

\begin{tabular}{lcccccc}
\hline & Crude OR & 95\% C.I. & $p$ & Adjusted OR & $95 \%$ C.I. & $p$ \\
\hline Antibiotic Linz vs. VAN & 11.385 & $1.419-91.352$ & $0.022^{*}$ & 4.472 & $0.977-20.466$ & 0.054 \\
Age (years) & 1.006 & $0.962-1.051$ & 0.807 & 0.963 & $0.920-1.008$ & 0.103 \\
Gender F vs. M & 0.821 & $0.239-2.817$ & 0.754 & 0.529 & $0.156-1.793$ & 0.307 \\
Comorbidity (Present vs. absent) & 1.065 & $0.216-5.243$ & 0.938 & 1.040 & $0.175-6.187$ & 0.965 \\
Duration (days) & 1.268 & $0.966-1.664$ & 0.087 & 1.162 & $0.859-1.570$ & 0.330 \\
Mean fluid balance after drug intake (ml) & 0.999 & $0.997-1.001$ & 0.345 & 0.998 & $0.996-1.000$ & $0.047^{*}$ \\
\hline CI: Confidence interval. & OR: Odds ratio. & $*$ * Significant at $p \leq 0.05$. & & & &
\end{tabular}

\section{Discussion}

Lactic acidosis is a rare but potentially lifethreatening complication of linezolid administration. We conducted a retrospective cohort study to evaluate the incidence of linezolid induced lactic acidosis. One hundred and fifty patients admitted to ICU after gastrointestinal tract surgery were enrolled in this study. Patients were divided into two groups: Those who used LZD and those who used Vancomycin with seventy-five patients in each group.

The current study revealed that the use of Linezolid was associated with a higher incidence of lactic acidosis compared to Vancomycin. However, logistic regression analysis revealed the lack ofstatistical significance increase in the risk of lactic acidosis with Linezolid use when adjusting for age, gender, patients' comorbidities and duration of drug use. Moreover, mean fluid balance was an independent risk factor for development of lactic acidosis, suggesting that a lower fluid balance maybe a contributing factor for the development of lactic acidosis in the studied patients.

LZD induced lactic acidosis was first reported by Apodaca and Rakita [3]. This was followed by several case reports in different patient populations. It was reported in patients with liver transplantation [7], lung transplantation [8], cancer [5], osteosarcoma [9], and Sickle cell anemia [10]. However, unlike our study these studies did not report other risk factors.

A retrospective cohort study carried by Mori et al., [4], at the National Hospital Organization Tokyo Medical Center (NTMC). Compared the incidence of lactic acidosis among Japanese patients $>20$ years old, who were administered either LZD (94 patients) or VAN (313 patients) for >_3 days from April 2014 to March 2016. The incidence of lactic acidosis with LZD therapy was significantly higher than that with VAN therapy. In a casecontrol study also conducted by Mori et al., [4], involving Japanese patients \_20 years old, 10 patients with Linezolid Associated Lactic Acidosis (LALA) were matched to 20 non-lactic acidosis patients by age and sex. Patients with LALA were more likely to have renal insufficiency than nonlactic acidosis patients that were in the univariate analysis reflecting that renal insufficiency was likely contributed to LALA [4]. Moreover, A Population pharmacokinetic analysis of linezolid applied to Japanese patients with infectious disease demonstrated that although renal function had little effect on the overall clearance of the drug, the total exposure to its metabolites is approximately more than 7- to 8-fold greater in patients with severe renal insufficiency (CLCR, 30-40 mL/min) than in subjects with normal renal function [11]. The previous studies suggested a correlation between renal insufficiency and (LZD-associated lactic acidosis) LALA. As the renal excretion is the main route of linezolid clearance. In the current study we excluded patients with renal impairment at base-line as to evaluate the possible LZD induced lactic acidosisafter exclusion of other risk factors for LALA.

LZD is metabolized mainly by the liver and more than $60 \%$ of lactic acid is also metabolized by the liver. According to Palenzuela et al., [5], the serum LZD concentration was found to be 4-6 times higher in a patient with liver dysfunction than that in normal patients. They reported 5 cases of Linezolid Associated Lactic acidosis: Three patients with liver cirrhosis and two patients with liver transplantation. Thus, liver dysfunction can be considered another risk factor for LZD-induced lactic acidosisby reducing the drug elimination resulting in mitochondrial toxicity [5].

According to Del Pozo et al., [13], two cases were reported with lactic acidosis due to long-term linezolid use by liver transplant recipients. Sequencing of mitochondrial rRNA genes demonstrated that both patients possessed a mitochondrial DNA polymorphism. Interestingly, in the work of Palenzuela and colleagues, genetic polymorphisms in the mitochondrial RNA-binding site were found in 3 patients [12]. Del Pozo et al., [13], stated that, 
despite these evidences, it is difficult to conclude a relationship between the presence of these polymorphisms and the susceptibility to linezolidinduced lactic acidosis due to the moderate prevalence of these polymorphisms in the general population [13]. However, in the current study patients with liver dysfunction were not included in the study to decrease confounding factors and evaluate the incidence of possible LZD induced lactic acidosis devoid of confounding factors in critically ill patients who had undergone post GIT-operative.

A previous retrospective studyconducted by $\mathrm{Im}$ et al., [5], included patients admitted to an 860-bed university hospital. The patients were dividedinto two groups, linezolid group (72) and control group (72) with exclusion of any risk factors for lactic acidosis except LZD. Im et al., [5], suggesteda longer duration of LZD use ( $>6$ weeks) as a risk factor for metabolic acidosis [5]. Though, in the current study LZD was used for shorter duration (7.4 days \pm 1.5 ), and there was a higher incidence than Vancomycin that didn't reach statistically significance.

Metabolic acidosis with acidemia causes a net shift of $\mathrm{K}+$ from the intracellular to the extracellular space leading to hyperkalemia, [14]. We recorded the $\mathrm{K}+$ level to evaluate the effect of metabolic acidosis on serum $\mathrm{K}+$ level. There wasn't statically significant difference in $\mathrm{K}+$ level between lactic acidosis and non-lactic acidosis group. To our knowledge, no other study has yet correlated the relation between $\mathrm{K}+$ level and lactic acidosis induced by LZD administration.

No previous study correlated lactic acidosis induced by LZD with fluid balance. In the current study a mean fluid balance was an independent risk factor for the development of lactic acidosis with an increase in mean fluid balance being significantly associated with reduced likelihood of developing lactic acidosis.

The current study has several limitations. This study was conducted at a single facility, Withrelatively small number of patients. Another limitation of the study is being retrospective in nature and of short duration.

\section{Conclusion:}

Based on the results obtained by this study on post GIT-operative patients, we founded an increased incidence of LZD induced lactic acidosis that did not reach statistical significance. So LZD is not associated with significant higher incidence of lactic acidosis in comparison to Vancomycin.

\section{Recommendation:}

Further studies with longer duration are necessary to evaluate the incidence of lactic acidosis in patients receiving LZD.

\section{References}

1- ROGER C., ROBERTS J.A. and MULLER L.: Clinical pharmacokinetics and pharmacodynamics of oxazolidinones. Clinical Pharmacokinetics, 57 (5): 559-575, 2018.

2- STACPOOLE P.W., WRIGHT E.C., BAUMGARTNER T.G., BERSIN R.M., BUCHALTER S., CURRY S.H., DUNCAN C., HARMAN E.M., HENDERSON G.N., JENKINSON S., LACHIN J.M., LORENZ A., SCHNEIDER S.H., SIEGEL J.H., SUMMER W.R., THOMPSON D., WOLFE C.L. and ZOROVICH B.: Natural history and course of acquired lactic acidosis in adults. The American Journal of Medicine, 97 (1): 47-54. https:// . doi.org/10.1016/0002-9343(94)90047-7, 1994.

3- APODACA A. A. and RAKITA R.M.: Linezolid-induced lactic acidosis. New England Journal of Medicine, 348 (1): 86-87, 2003.

4- MORI N., KAMIMURA Y., KIMURA Y., HIROSE S., AOKI Y. and BITO S.: Comparative analysis of lactic acidosis induced by linezolid and vancomycin therapy using cohort and case-control studies of incidence and associated risk factors. European Journal of Clinical Pharmacology, 74 (4): 405-411. https://doi.org/10.1007/ s00228-017-2377-1, 2018.

5- IM J.H., BAEK J.H., KWON H.Y. and LEE J. S.: Incidence and risk factors of linezolid-induced lactic acidosis. International Journal of Infectious Diseases, 31: e47-e52. https://doi.org/10.1016/j.ijid.2014.12.009, 2015.

6- HINKLE D.E., WIERSMA W. and JURS S.G.: Applied statistics for the behavioral sciences (Vol. 663). Houghton Mifflin College Division, 2003.

7- PEA F., SCUDELLER L., LUGANO M., BACCARANI U., PAVAN F., TAVIO M., FURLANUT M., ROCCA G. DELLA, BRESADOLA F. and MKVIALE P.: Hyperlactacidemia potentially due to linezolid overexposure in a liver transplant recipient. Clinical Infectious Diseases, 42 (3): 434-435, 2006.

8- PROTTI A., RONCHI D., BASSI G., FORTUNATO F., BORDONI A., RIZZUTI T. and FUMAGALLI R.: Changes in whole-body oxygen consumption and skeletal muscle mitochondria during linezolid-induced lactic acidosis. Critical Care Medicine, 44 (7): e579-e582.4, 2016.

9- GARRABOU G., SORIANO A., LÓPEZ S., GUALLAR J.P., GIRALT M., VILLARROYA F., MARTÍNEZ J.A., CASADEMONT J., CARDELLACH F. and MENSA J.: Reversible inhibition of mitochondrial protein synthesis during linezolid-related hyperlactatemia. Antimicrobial Agents and Chemotherapy, 51 (3): 962-967, 2007.

10- THORELL E.A., SHARMA M., JACKSON M.A., SELVARANGAN R. and WOODS G.M.: Disseminated nontuberculous mycobacterial infections in sickle cell anemia patients. Journal of Pediatric Hematology/Oncology, 28 (10): 678-681, 2006.

11- ABE S., CHIBA K., CIRINCIONE B., GRASELA T.H., ITO K. and SUWA T.: Population pharmacokinetic analysis 
of linezolid in patients with infectious disease: application to lower body weight and elderly patients. The Journal of Clinical Pharmacology, 49 (9): 1071-1078, 2009.

12- HIRANO MICHIO, PALENZUELA L., HAHN N.M., NELSON R.P., ARNO J.N., SCHOBERT C., BETHEL R., OSTROWSKI L.A., SHARMA M.R. and DATTA P.P.: Does linezolid cause lactic acidosis by inhibiting mitochondrial protein synthesis? Clinical Infectious Diseases, 40 (12): e113-e116, 2005.

13- DEL POZO J.L., FERNÁNDEZ-ROS N., SÁEZ E., HER-
RERO J.I., YUSTE J.R. and BANALES J.M.: Linezolidinduced lactic acidosis in two liver transplant patients with the mitochondrial DNA A2706G polymorphism. Antimicrobial Agents and Chemotherapy, 58 (7): 4227 4229, 2014.

14- ARONSON P.S. and GIEBISCH, G.: Effects of pH on potassium: New explanations for old observations. Journal of the American Society of Nephrology, 22 (11): 19811989, 2005. Does linezolid cause lactic acidosis by inhibiting mitochondrial protein synthesis? Clinical Infectious Diseases, 40 (12): e113-e116, 2011.

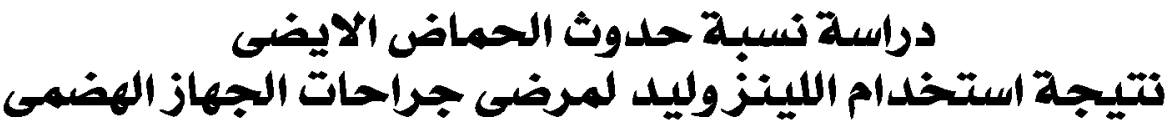

يعد اللينزوليد أحد المضادات الحيوية التابعة لمجموعة الو كسانوليدينونز ويستخدم فى علاج الالتهابات التى تسيبها البكتيريا إيجابية

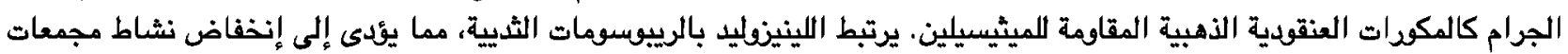

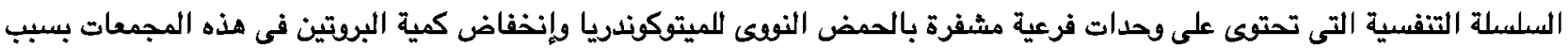

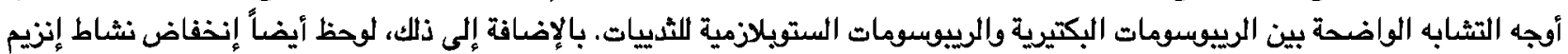

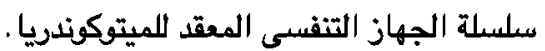

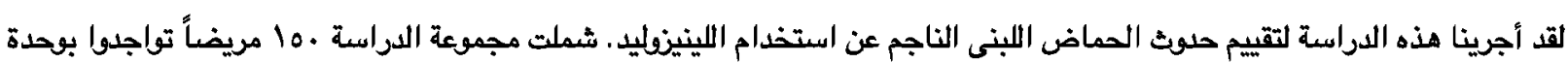

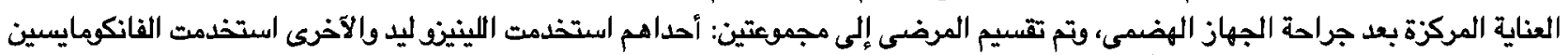

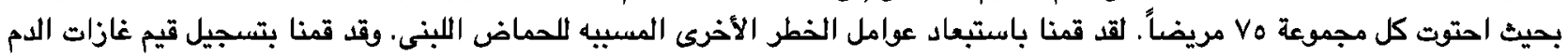

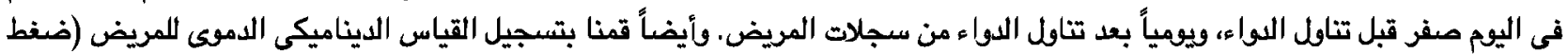

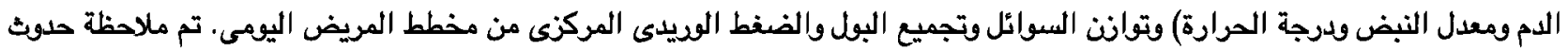

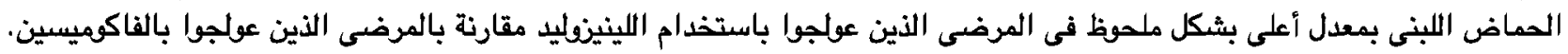

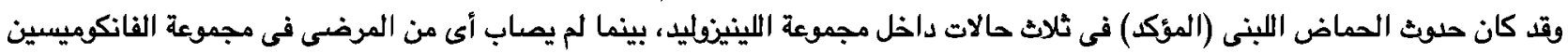

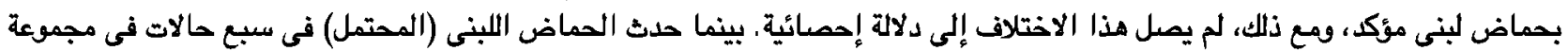

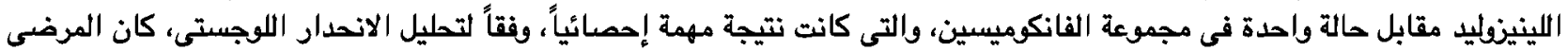

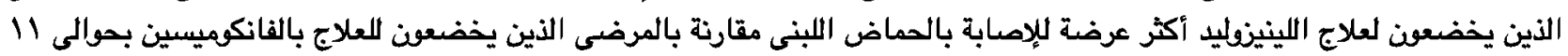

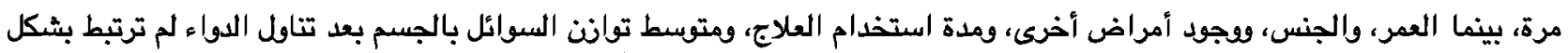

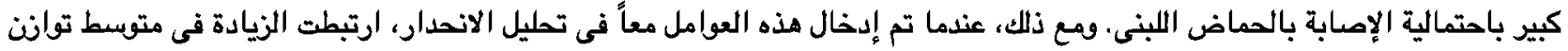

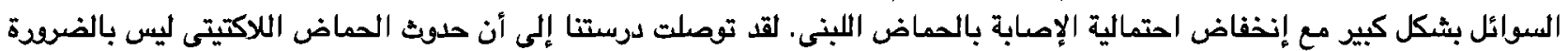
مرتبطاً باستخدام اللينيزوليد. 